\title{
The importance of knowledge on the evaluation criteria in university scientific research projects
}

\author{
Cristian Marius Toma ${ }^{1,2}$ \\ ${ }^{1}$ „Al. I. Cuza” University of Iasi, Romania, \\ ${ }^{2}$ „Grigore T. Popa” University of Medicine and Pharmacy Iasi, Romania
}

\begin{abstract}
Scientific research is part of any university mission, at least of big universities, as it represents the complementary element required by the learning process. A learning process based on engendering knowledge is much more valuable and competitive than a learning process which is reduced to a mere transfer of knowledge from the teacher to the students. The important universities consider that "the development of scientific research as a fundamental competence is essential for survival in a more and more competitive environment on global level and that is why, research should be part of the university mission",

This study aims to highlight how important it is for the university members to be aware of the evaluation criteria for the research projects they undertake. For this purpose, I have interviewed a number of 55 persons, project managers and team members in the projects from the "Research for Excellency" program and the National Plan of Research, Development and Innovation PN II 2007 2013.

Out of the evaluation criteria for research, the most important ones were considered to be the scientific quality of the project and the quality of the human resources involved in the project.
\end{abstract}

\section{Key words}

evaluation, evaluation criteria, scientific research, research project

\section{JEL Codes: I 21, I 23}

\section{Introduction}

The society based on knowledge has the mission to engender knowledge, disseminate it through education and professional training, spread and put it into value in innovations and technological development. Even more, investments in research, innovation and technological transfer ensure the economical development of the society. In a certain measure, these desiderata are fulfilled due to the role played by higher education in general and the university research in particular.

The development of scientific research increases the chances of receiving funds from government bodies and especially from the industrial field. At the same time, the reputation of the university and its social role is reinforced in the community it belongs to.

In the same train of thought, Bratianu et al (2007) assert that ,in order to change the scientific research in a fundamental competence for the university, a competence which would confer consistency and power in the accomplishment of the competitive advantage,

1 Hazelkorn E. (2006), University research management. Developing research in new institution, OECD Publishing 
there is needed a strategic decision coming from the management, on one hand, and the elaboration of a specific strategy backed up by an adequate allotment of funds, on the other hand"2.

\section{The purpose of the study}

Starting from these considerations, I have made a study which aims to highlight the importance of the evaluation criteria in scientific research undertaken in the research projects. For this purpose, I have interviewed a number of 55 persons, managers and team members in the research projects and the "Research for Excellency" program and in the National Plan for Research, Development and Innovation PN II 2007 - 2013.

\section{Materials and Method}

The first evaluation criterion taken into consideration was the scientific quality of the research project expressed in the following:

- Adequate knowledge and up-dated presentation of the accomplishments in any field;

- Originality and innovative character of the research project;

- Relevance of the purposes of the research project on national and international level;

- Degree of interdisciplinary character (where it applies);

- Agreement between the research methodology and objectives of the project.

The second criterion under study was the quality of human resources which have to be part of the project. Hence, there were analyzed the following issues:

- Scientific competence of the project manager, estimated mainly in the articles published in ISI reviews and other international data bases;

- Managerial competence of the project manager, his experience and previous results obtained in other research projects;

- Quality and experience of the research team members, estimated mainly in the articles published in ISI reviews and other international data bases;

- Promotability of young researchers ( $\mathrm{PhD}$ and Master students) in the research projects with a clear description of their role in the development of the research projects.

Another important criterion we have planned to monitor was the project implementation method. Regarding this issue, we have analyzed the following:

- The quality of the project management - taking into consideration the coherence of the work plan and the associated activities;

- The way of disseminating the results of the project

- Feasibility and credibility of the project, taking into account the human and financial resources of the project;

- The approach of the ethical problems of the project.

One more important criterion investigated in the study was the usage of resources in the project, respectively :

- Degree of adequate equipment and experiment devices as well as the presence of adequate equipment and devices in the institution which undertakes the project

- Optimal dimensions of budget chapters in the research project.

These parameters were ranged according to features expressed in percentages: very important, important, less important.

${ }^{2}$ Bratianu C. et col (2007), Managementul cercetării ştiințifice universitare / The Management of University Scientific Reasearch, Ed. Economică, Bucureşti, p. 24 


\section{Results and discussions}

As regards the criterion "the scientific quality of the research project", most of the interviewed people (40, respectively $73 \%$ ) have shown that this criterion is very important (Tabel 1, Figure 1).

Tabel 1. The scientific quality of the research project

\begin{tabular}{|c|c|c|c|}
\hline Criterion & Very important & Important & $\begin{array}{c}\text { Less } \\
\text { important }\end{array}$ \\
\hline $\begin{array}{c}\text { The scientific quality of } \\
\text { the research project }\end{array}$ & $40(73 \%)$ & $10(18 \%)$ & $5(9 \%)$ \\
\hline
\end{tabular}

The scientific quality of the research project

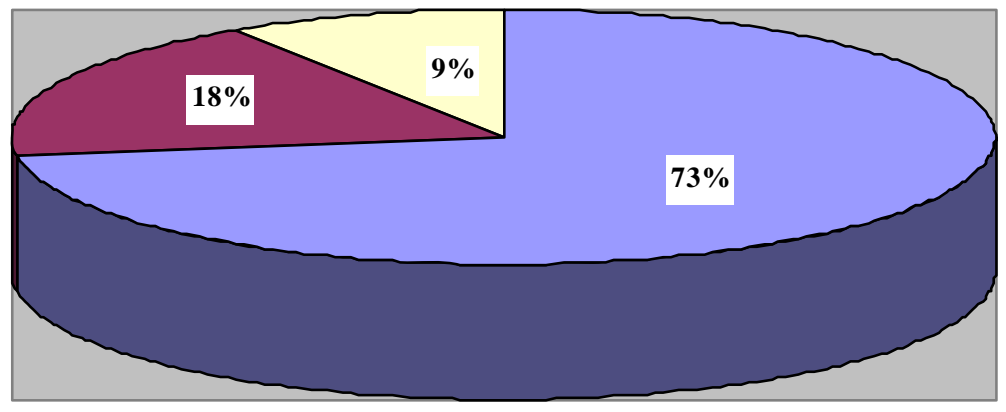

$\square$ Very important $\square$ Important

$\square$ Less Important

Figure. 1. The scientific quality of the research project

Tabel 2 and Figure 2 present the answers given by the interviewed persons related to the quality of human resources which should be included in the project team. 36 subjects (respectively 68\%) considered this criterion to be very important.

Tabel 2. The quality of human resources

\begin{tabular}{|c|c|c|c|}
\hline Criterion & Very important & Important & $\begin{array}{c}\text { Less } \\
\text { important }\end{array}$ \\
\hline $\begin{array}{c}\text { The quality of human } \\
\text { resources }\end{array}$ & $36(68 \%)$ & $9(17 \%)$ & $8(15 \%)$ \\
\hline
\end{tabular}


The quality of human resources

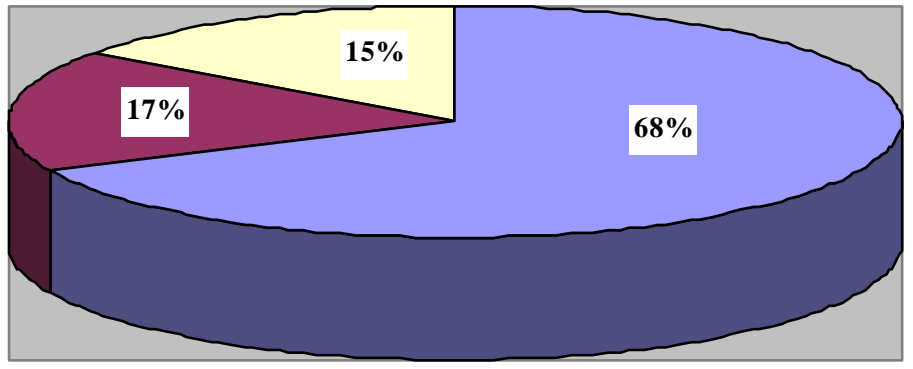

$\square$ Very important

$\square$ Important

$\square$ Less important

Figure. 2. The quality of human resources

Tabel 3 and Figure 3 display the answers given by the interviewed persons related to the project implementation method, most of them, namely 34 (respectively 62\%) also considered it to be a very important criterion.

Tabelul 3. The project implementation method

\begin{tabular}{|c|c|c|c|}
\hline Criterion & Very important & Important & $\begin{array}{c}\text { Less } \\
\text { important }\end{array}$ \\
\hline $\begin{array}{c}\text { The project } \\
\text { implementation method }\end{array}$ & $34(62 \%)$ & $12(22 \%)$ & $9(16 \%)$ \\
\hline
\end{tabular}

The project implementation method

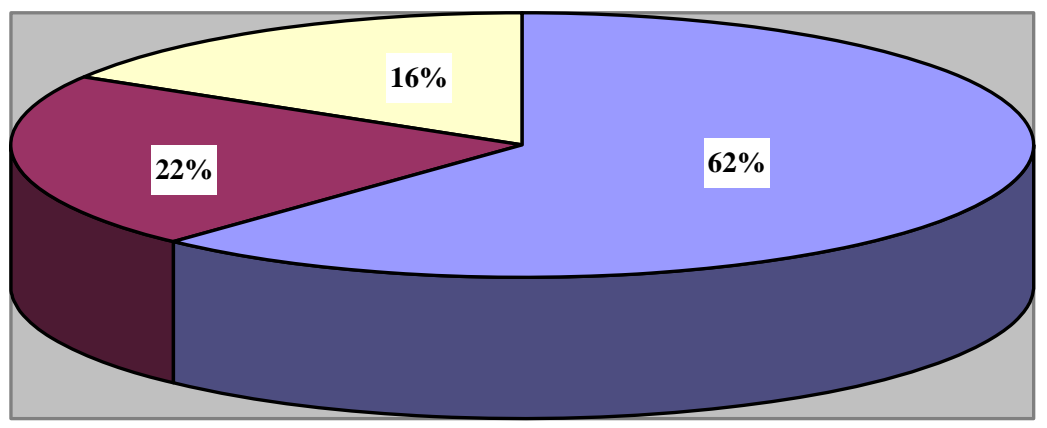

Figure. 3. The project implementation method

Regarding the usage of resources in the project, 26 (47\%) subjects considered it to be less important, $10(18 \%)$ - important and only 19 of them (35\%) ranked it as very important (Tabel 4, Figure 4). 
Studies and Scientific Researches - Economic Edition, no. 15, 2010

Tabelul nr. 4. The usage of resources in the project

\begin{tabular}{|c|c|c|c|}
\hline Criterion & Very important & Important & $\begin{array}{c}\text { Less } \\
\text { important }\end{array}$ \\
\hline $\begin{array}{c}\text { The usage of resources in } \\
\text { the project }\end{array}$ & $19(35 \%)$ & $10(18 \%)$ & $26(47 \%)$ \\
\hline
\end{tabular}

The usage of resources in the project

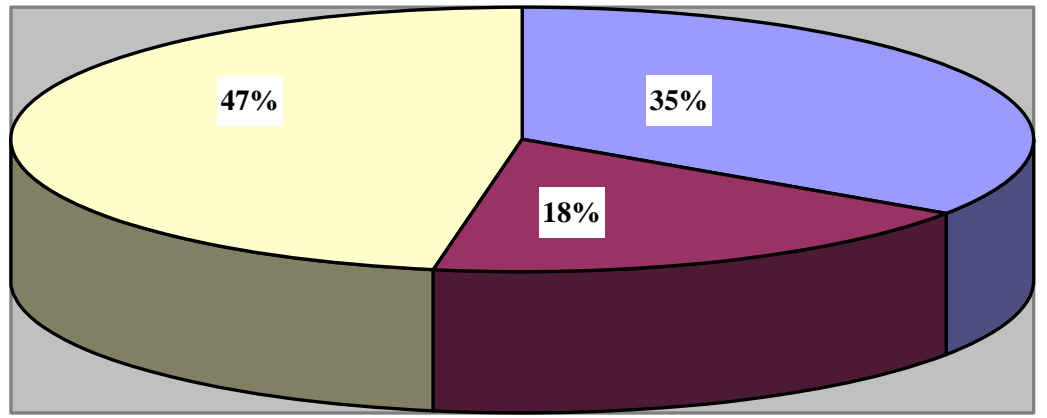

$\square$ Very important $\square$ Important

口Less Important

Figure. 4. The usage of resources in the project

Evaluation criteria used in university scrientific research

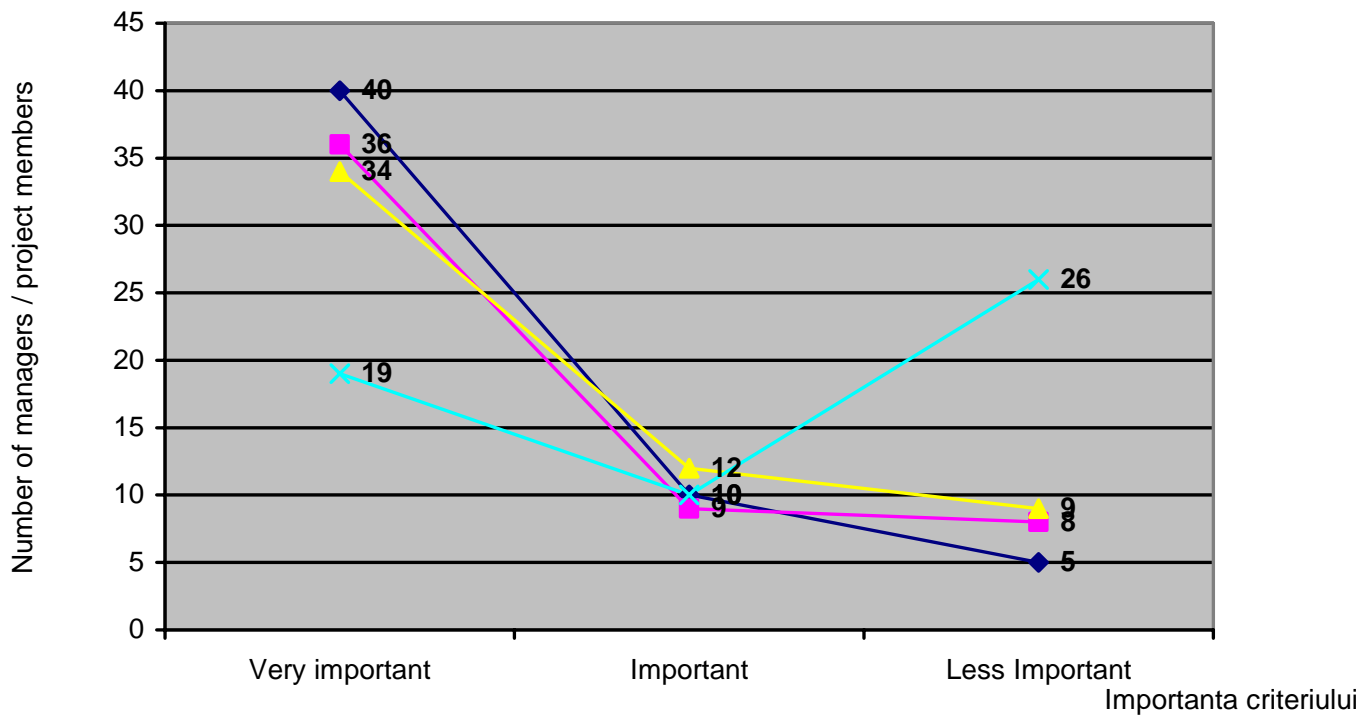

Figure. 5. Evaluation criteria used in university scientific research projects 


\section{Conclusions}

The study we have undertaken has proved that the most important criterion in the view of the interviewed people is the scientific quality of the research project (40 subjects, representing $73 \%$ from the total of interviewed persons).

This criterion is followed, in the order of importance, by the quality of human resources, 36 $(68 \%)$ of the subjects considered it was very important.

The project implementation method is a less important criterion in comparison to the scientific quality of the project and the quality of human resources, but it does not lack importance, as 34 persons (62\%) from the subjects ranked it as very important.

Out of the evaluation parameters used in university scientific research, in the view of the subjects, the usage of project resources was estimated as being less important, as only 19 $(35 \%)$ of the subjects asserted it was very important.

In conclusion, this study shows that the most important evaluation criterion in scientific research undertaken in research projects is the scientific quality of the research project, followed, in the order of importance by the quality of human resources, the project implementation method and finally the usage of project resources.

\section{Bibliography}

1. Armstrong M. (2003), Managementul resurselor umane: manual de practică / The Management of Human Resources: a practical textbook, Editura Codecs, Bucureşti

2. Armstrong M. (2006), Performance Management, Kogan Page Ltd., London

3. Bratianu C., Curaj A., Vasilache S., Baltei C. (2007), Managementul cercetării ştiințifice universitare, Ed. Economică, Bucureşti

4. Bendoly E., Swink M. (200\&), Moderating effects of information access on project management behavior, performance and perceptions, Journal of Operations Management, 25, 604-622.

5. Hazelkorn E. (2006), University research management. Developing research in new institution, OECD Publishing

6. Isoc D. (2007), Managementul proiectelor de cercetare: ghid practice, Ed. Risoprint, Cluj-Napoca

7. Isoc D. (2007), Managementul proiectelor de cercetare: proiecte cu finanțare publică națională şi internaționala; capitalizarea şi gestiunea proprietății intelectuale: ghid practic, Ed. Risoprint, Cluj-Napoca

8. Scott-Young C., Samson D. (2009), Team management for fast projects: an empirical study of process industries, International Journal of Operations \& Production Management, 29(6), 612-635

9. Zait D., Spalanzani A. (2006), Cercetarea in economie si management. Repere epistemologice si metodologice, Ed. Economica, Bucuresti

10. Winter M., Smith C., Morris P., Ciemil S. (2006), Directions for future research in project management: The main findings of a UK government-funded research network, International Journal of Project Management, 24, 638-649

11. www.ancs.ro - The national Authority for Scientific Research.

12. www.cncsis.ro - The National Committee of Scientific Research in High Education. 